\title{
THE IMPACT OF INSTITUTIONAL EFFICIENCY ON THE FOREIGN DIRECT INVESTMENT INFLOWS IN DEVELOPING COUNTRIES

\author{
Alena D. Galenkova ${ }^{1}$, Igor M. Drapkin ${ }^{2}$, Oleg S. Mariev ${ }^{3}$
}

\begin{abstract}
The aim of this paper is assessing the impact of the effectiveness of the country's institutions on the foreign direct investment inflows in developing countries with the use of econometric modeling. We put forward a hypothesis about the positive impact of institutional factors on the foreign direct investment inflow. The overall influence of institutions is evaluated using the multiplication of the index of economic freedom and the state fragility index, as two indices, most fully characterizing the disjoint groups of the institutions. To achieve the main goal of the study, we accomplish the econometric modeling based on data from the World Bank, the Heritage Foundation and the Fund for Peace from 1995 to 2015. As the main tool of econometric analysis, a panel regression with fixed effects is used and the technique of a two-step least-squares regression analysis method with instrumental variables is used to solve a possible endogeneity problem in the model. As a result of the study, an assessment of the overall impact of institutional factors through the composition of indices was carried out and a hypothesis about the positive impact of institutional factors on the inflow of foreign direct investment in developing countries was confirmed.
\end{abstract}

JEL Classification Numbers: F21; DOI: http://dx.doi.org/10.12955/cbup.v6.1146

Keywords: foreign direct investment, institutional factors, developing countries, econometric analysis, panel data.

\section{Introduction}

Under current conditions, the emerging political and economic shocks dictate the need to develop measures to preserve and improve the country's investment climate. For developing countries, which are in most cases recipients of foreign direct investment, it is important to identify factors of foreign direct investment inflows, which in turn are recognized as a catalyst for economic growth. Institutional factors influence the inflow of foreign direct investment by reducing transaction and information costs, as well as reducing uncertainty among investors and strengthening their confidence in the state.

In this paper authors discuss the possibility to estimate the impact of the effectiveness of the country's institutions on the foreign direct investment inflows in developing countries using the multiplication of two institute indexes and the results of estimation by econometric modeling.

\section{Theoretical Basis of the Study}

The study of the institutions efficiency impact in developing countries on the inflow of foreign direct investment implies the use of various indices characterizing both narrow and broad groups of institutions. However, it is also necessary to investigate the overall effect of the institutions effectiveness. In this study, it is proposed to do this with the multiplication of the index of economic freedom and the state fragility index. Such an approach allows us to assess the influence of the total set of the country's institutions on the inflow of foreign direct investment, since both indices broadly cover groups of institutions, without overlapping in their components.

The index of economic freedom is a rating that assesses the level of economic freedom in the countries of the world. It is issued by the American research center of The Heritage Foundation since 1995. The experts of The Heritage Foundation research center define economic freedom as "the absence of government interference or obstruction of the production, distribution and consumption of goods and services, except for the necessary protection and support of freedom for citizens as such". The index of economic freedom is considered to be a strong index characterizing economic freedom and institutions and is calculated as the arithmetic mean of ten benchmarks.

The state fragility index is issued by the research center of The Fund for Peace. In preparing the Index, all countries covered by the study are analyzed using a systemic conflict assessment tool. The analysis is conducted based on twelve criteria of state insolvency, which are united into three groups: social, economic and military-political. For an overall assessment of the state of the country, experts analyze

\footnotetext{
${ }^{1}$ Graduate School of Economics and Management, Ural Federal University, Yekaterinburg, Russian Federation, agalenkova@mail.ru

${ }^{2}$ Graduate School of Economics and Management, Ural Federal University, Yekaterinburg, Russian Federation, i.m.drapkin@urfu.ru

${ }^{3}$ Graduate School of Economics and Management, Ural Federal University and Institute of Economics, Ural Branch of the Russian Academy of Sciences; Yekaterinburg, Russian Federation, o.s.mariev@urfu.ru
} 
the ability of five key state institutions - political leadership, the army, the police, the judiciary and civil services - to ensure the security of the state and its citizens.

In this paper, we propose to evaluate the relevance of the results of econometric modeling using the multiplication of the economic freedom index and the state fragility index as a variable characterizing the overall effectiveness of institutions in the country.

Foreign direct investment, like any macroeconomic phenomena, have their own ramified system of factors affecting their magnitude. Many practitioners and researchers have studied the factors of attracting foreign direct investment; some of them have paid special attention to institutional indicators as one of the factors. In most cases, the authors used several indexes in studies that characterize a wide range of institutions, such as the public administration performance index as Fabry \& Zeghni (2006) did or the index of economic freedom as Mariev et al. (2016) or Tintin (2013) did; but some authors limited themselves to an index characterizing a narrow set of institutions, for example, the rule of law index, that is described in work of Hou et al. (2014). Table 1 presents the main recent empirical studies and their results.

In this study, the authors focused on two internationally comparable composite indices describing the effectiveness of broad groups of institutions: the index of economic freedom and the insolvency index of the state. In addition, these indices have no coincidence in their components, which makes it possible to cover the institutions of the country most widely.

\begin{tabular}{|lll|}
\hline \multicolumn{1}{|c|}{ Table 1. Summary of Empirical Research } & \multicolumn{1}{c|}{$\begin{array}{c}\text { Journal, year of } \\
\text { publishing }\end{array}$} & \multicolumn{1}{c|}{ Determinants and main results of survey } \\
\hline $\begin{array}{l}\text { The determinants of inward foreign } \\
\text { direct investment: Evidence from } \\
\text { the European regions, Maza \& } \\
\text { Villaverde (2015) }\end{array}$ & $\begin{array}{l}\text { International Business } \\
\text { Review 24 (2015) }\end{array}$ & $\begin{array}{l}\text { Economic potential, labor market } \\
\text { characteristics, technological progress and } \\
\text { regional competitiveness have a significant } \\
\text { impact on the localization of foreign direct } \\
\text { investment inflows. }\end{array}$ \\
\hline $\begin{array}{l}\text { The determinants of foreign direct } \\
\text { investment inflows in the Central } \\
\text { and Eastern European Countries: } \\
\text { The importance of institutions, } \\
\text { Tintin (2013) }\end{array}$ & $\begin{array}{l}\text { Communist and Post- } \\
\text { Communist Studies 46 } \\
\text { (2013) }\end{array}$ & $\begin{array}{l}\text { Institutional variables: the index of economic } \\
\text { freedom, the state's insolvency rating, } \\
\text { political rights and civil liberties are reliable } \\
\text { determinants of foreign direct investment. }\end{array}$ \\
\hline $\begin{array}{l}\text { How former communist countries of } \\
\text { Europe may attract inward foreign } \\
\text { direct investment? A matter of } \\
\text { institutions, Fabry \& Zeghni (2006) }\end{array}$ & $\begin{array}{l}\text { Communist and Post- } \\
\text { (2012) }\end{array}$ & $\begin{array}{l}\text { The development of institutions creating } \\
\text { markets has the greatest impact on the inflow } \\
\text { of foreign direct investment. }\end{array}$ \\
$\begin{array}{l}\text { Institutions and Foreign Direct } \\
\begin{array}{l}\text { Investment: China versus the Rest } \\
\text { of the World, Fan (2009) }\end{array}\end{array}$ & $\begin{array}{l}\text { World Development } \\
\text { Vol. 37, No. 4, (2012) }\end{array}$ & $\begin{array}{l}\text { FDI is attracted by countries with a good } \\
\text { government record, which shows a stable } \\
\text { and high previous growth, which have a } \\
\text { government that performs its duty } \\
\text { qualitatively, and in which the rule of law } \\
\text { prevails. }\end{array}$ \\
\hline $\begin{array}{l}\text { Foreign direct investment and } \\
\text { institutional quality: Some } \\
\text { empirical evidence, Buchanan et al. } \\
\text { (2012) }\end{array}$ & $\begin{array}{l}\text { International Review } \\
\text { of Financial Analysis }\end{array}$ & $\begin{array}{l}\text { The quality of institutions has a positive and } \\
\text { significant impact on foreign direct } \\
\text { investment. }\end{array}$ \\
\hline Source: Authors & & \\
\hline
\end{tabular}

The methodology of conducting an econometric study of foreign direct investment in most articles have no significant differences. Researchers, that we have mentioned in Table 1, agree that modeling of the FDI should be carried out using panel data and the method of least squares, and for the study of FDI in developing countries, the absence of a variable measuring the distance is typical.

\section{Data and Methodology}

The econometric model was constructed on the dataset comprising 146 developing countries (World Bank classification, due to the incompleteness of available data, 31 countries were excluded, total - 115 countries in the sample) from 1995 to 2015 based on World Bank databases, the Heritage Foundation and the Fund for Peace. The initial specification of the model is presented below: 


$$
\begin{gathered}
\ln F D I=\beta_{0}+\beta_{1} G D P g_{i t}+\beta_{2} \ln T_{O I}+\beta_{3} \ln D e f l_{i t}+\beta_{4} I_{i n} U s_{i t}+\beta_{5} U_{n e m p l} \\
\beta_{6} L F T E_{i t}+\beta_{7} H T E_{i t}+\beta_{8} \text { inst }_{i t}+\varepsilon_{i t}
\end{gathered}
$$

The model includes the following macroeconomic and social factors: the growth rate of GDP (GDPg), the trade openness index (TOI), the GDP deflator (Defl), the number of Internet users per 100 population (IntUs), the unemployment rate (Unempl), the percentage of the labor force with higher education (LFTE), the share of high-tech exports in total exports (HTE), the multiplication of economic freedom and state fragility indexes (inst). The choice of variables was due to the results of previous empirical studies (see Table 1). Variables measured not in the percentage were taken with the logarithms aiming to transition to elasticities. The explained variable is the logarithm of the foreign direct investment inflow. All the variables, their codes, databases and hypothesis about sign of coefficients are in the Appendix. Hypotheses about coefficient signs were built on the literature reviews about foreign direct investment determinants.

The hypothesis of the study is the positive effect of the multiplication of indices (the effectiveness of institutions) on the inflow of foreign direct investment in developing countries. This means that we expect foreign direct investment inflows will grow with the increasing of institutional effectiveness in developing countries. When this hypothesis is confirmed, this variable can be used in further studies on this topic.

The following steps were implemented during the modeling: exclusion of non-significant LFTE, IntUs and HTE variables (the coefficients of the variables turned out to be statistically insignificant), testing of the first and second degree lags for insignificant variables (accounting for the time lag), testing models for individual effects with the Breusch-Pagan test (described by Wooldridge, 2008), which showed their presence, then testing models with fixed and random effects. The lags of the first and second degree variables were also tested as instrumental variables. This choice makes economic sense because investors react to changes in the economy with some delay; current investment is made with an orientation to the indicators of the past. Thus, for each variable, a regression was individually constructed using a two-step least squares method, replacing the variable suspected on endogeneity with instrumental variables, during which the strength of the instrumental variables was verified with the help of the Weak IV test (described by Wooldridge, 2008).

According to the results of the econometric study, it was revealed that the lags of the variables of the first degree and the second degree are strong instrumental variables for the variables TOI and IntUs, the lags of the variables IEF, SFI, Unempl and LFTE did not pass the Sargan test (described by Wooldridge, 2008 ) on the validity of instrumental variables. The resulting model, containing instrumental variables for LTOI and Intus, was compared to a model with fixed effects with the same variables using the Hausman test. According to the results of the Hausman test, the difference between the coefficients is systematic, so the specification with fixed effects is more correct.

The final step in econometric modeling was testing for heteroscedasticity, which is present in any model on panel data, and correction of standard errors by White's method.

It should be noted that all our models are models with fixed effects. This can be intuitively explained by the fact that the sample includes most of the countries from the set of developing countries.

\section{Results}

The final specification of the panel data model with fixed effects is presented in Table 2 .

\begin{tabular}{|l|c|c|}
\hline \multicolumn{1}{|c|}{ Table 2. Econometric modeling of foreign direct investment inflows to developing countries } \\
\hline \multicolumn{1}{|c|}{ Variable } & Code & Coefficient \\
\hline GDP growth rate (\%) & GDPg & $0.027155^{* * *}$ \\
\hline Logarithm of the openness index (1 period lag) & lnTOI L1. & $1.190428^{* * *}$ \\
\hline The logarithm of the GDP deflator & lnDefl & $0.114201^{* * *}$ \\
\hline Unemployment rate (\%) & Unempl & $-0.05852^{* * *}$ \\
\hline $\begin{array}{l}\text { The multiplication of the indices of economic freedom and } \\
\text { insolvency of the state (1 period lag) }\end{array}$ & inst L1. & $0.00028^{*}$ \\
\hline Constant & cons & 0.890097 \\
\hline $\begin{array}{l}\text { N=896; R-sq: within=0.1068; between=0.4366; overall=0.3910. Prob >F=0.0000 } \\
\text { Notes: * - significance level 10\%, ** - significance level 5\%, *** - significance level 1\%. } \\
\text { Source: Authors }\end{array}$ \\
\hline
\end{tabular}


Thus, the growth rate of GDP, the trade openness index with the lag of the first degree, the GDP deflator have a positive impact on the inflow of foreign direct investment, the unemployment rate has a negative impact. The number of Internet users per 100 population, share of high-tech exports in total exports and the percentage of labor force with higher education turned out to be statistically insignificant.

In general, throughout the sample, institutions have a positive impact on the inflow of foreign direct investment into developing countries with a lag of one year; the coefficient for the variable is significant, which implies that the hypothesis was econometrically confirmed. The resulting lags due to the influence of the institutional variable are understandable from the point of view of investors and citizens: the effect of any institutional changes, being the state policy on taxes or the leakage of highly skilled personnel, will be felt after a certain period of time. A variable characterizing the influence of institutions in general (not by institutional groups) on the inflow of foreign direct investment has shown relevant results, which makes it possible to use the presented approach in further research.

\section{Conclusion}

As a result of the analysis of the impact of various factors on the inflow of foreign direct investment, the issue of the structural set of measures that governments can make to increase the volume of attracted foreign investment arises. A general positive effect will be observed with sustained economic growth and stabilization of the economic and political situation in the country. Increased economic integration and international openness of the country will also lead to an increase in investors' interest in it. Excessive interference of state institutions in the economy is fraught with a decrease in the inflow of foreign investment, but effective security of citizens and their freedom will have the opposite effect. The implementation of a number of systemic measures to increase the effectiveness of existing institutions at the legislative, executive, project and other levels or the transplantation of existing institutions already established in developed countries will allow increasing the inflow of foreign direct investment in the medium term.

These results allow us to use the multiplication of the indices of economic freedom and insolvency of the state in future studies as a characteristic of institutional efficiency in developing countries to estimate the impact on subsamples of developing countries.

\section{Acknowledgements}

This research was supported by the President of Russia grant "Institutional determinants of foreign direct investment inflows: country and region level analysis" (grant No. MD 6402.2018.6).

\section{References}

Buchanan B. G., Le Q. V., Rishi M. (2012) Foreign direct investment and institutional quality: Some empirical evidence. International Review of Financial Analysis. 21, pp. 81-89.

Fabry N., Zeghni S. (2006) How former communist countries of Europe may attract inward foreign direct investment? A matter of institutions. Communist and Post-Communist Studies. 39, pp. 201-219.

Faeth I. (2009) Determinants of foreign direct investment. A tale of nine theoretical models. Journal of Economic Surveys. 23(1), pp. 165-196.

Fan J. P. H. (2009) Institutions and Foreign Direct Investment: China versus the Rest of the World. World Development. 37(4), pp. 852-865.

Gokalp M. F., Yildirim A. (2016) Institutions and Economic Performance: A Review on the Developing Countries. Procedia Economics and Finance. 38, pp. 347-359.

Hou K., Luke Chan M.W., Li X., Mountaina D. C. (2014) Foreign direct investment and its determinants: A regional panel causality analysis. The Quarterly Review of Economics and Finance. 54, pp. 579-589.

Mariev O., Drapkin I., Chukavina K. (2016) Is Russia successful in attracting foreign direct investment? Evidence based on gravity model estimation. Review Of Economic Perspectives. 16(3), pp. 245-267

Maza A., Villaverde J. (2015) The determinants of inward foreign direct investment: Evidence from the European regions. International Business Review. 24, pp. 209-223.

The Fund for Peace (2017) Fragile States Index presented by The Fund for Peace: Global Data. Retrieved from: http://fundforpeace.org/fsi/data/

The Heritage Foundation (2017) Index of Economic Freedom: Explore the Data. Retrieved from: http://www.heritage.org/index/explore

The World Bank Group (2017) The World Bank Database: World Development Indicators. Retrieved from: http://databank.worldbank.org/data/reports.aspx?source= 2\&series=SP.POP.TOTL\&country=\#

Tintin C. (2013) The determinants of foreign direct investment inflows in the Central and Eastern European Countries: The importance of institutions. Communist and Post-Communist Studies. 46, pp. 287-298 
Wooldridge J. (2008) Introductory Econometrics - A Modern Approach. Washington: ECON., 910.

WorldBank (2017) New classification of countries. Retrieved from: http://www.vsemirnyjbank.org/ru/news/pressrelease/2013/07/02/new-country-classification

\section{Appendix}

\begin{tabular}{|c|c|c|c|}
\hline Variable & Code & $\begin{array}{c}\text { Expected sign } \\
\text { of coefficient }\end{array}$ & Database \\
\hline $\begin{array}{c}\text { Net inflow of foreign direct } \\
\text { investment }\end{array}$ & FDI & + & WorldBank Database \\
\hline Growth rate of GDP (\%) & GDPg & - & WorldBank Database \\
\hline $\begin{array}{c}\text { Gumber of Internet users per } \\
100 \text { population (\%) }\end{array}$ & Defl & - & WorldBank Database \\
\hline Unemployment rate (\%) & Unempl & $+/-$ & WorldBank Database \\
\hline $\begin{array}{c}\text { Trade Openness Index } \\
\text { Percentage of the labor force } \\
\text { with higher education (\%) }\end{array}$ & TOI & + & $\begin{array}{c}\text { Calculated by the } \\
\text { authors on the basis } \\
\text { of WorldBank } \\
\text { Database }\end{array}$ \\
\hline $\begin{array}{c}\text { Share of high-tech exports in } \\
\text { total exports (\%) }\end{array}$ & LFTE & - & \begin{tabular}{c} 
WorldBank Database \\
\hline $\begin{array}{c}\text { Overall influence of } \\
\text { institutions (multiplication of } \\
\text { Index of Economic Freedom } \\
\text { and State Fragility Index) }\end{array}$
\end{tabular} \\
\hline
\end{tabular}

